\title{
Instructional Leadership Potential among School Principals in Pakistan
}

\author{
Muhammad Niqab ${ }^{1}$, Sailesh Sharma ${ }^{1}$, Leong Mei Wei ${ }^{1} \&$ Shafinaz Bt A. Maulod ${ }^{1}$ \\ ${ }^{1}$ Institute of Educational Leadership, University Malaya, Kuala Lumpur, Malaysia \\ Correspondence: Muhammad Niqab, Institute of Educational Leadership, University Malaya, Kuala Lumpur, \\ Malaysia. Tel: 60-146-277-966. E-mail: niqab2@gmail.com
}

Received: March 24, 2014 Accepted: April 25, 2014 Online Published: May 27, 2014

doi:10.5539/ies.v7n6p74

URL: http://dx.doi.org/10.5539/ies.v7n6p74

\begin{abstract}
This study highlights the pivotal role of the school principal in relation to organizational commitment and expected student outcomes in schools in Pakistan. By critically examining the available literature, and by evaluating relevant data, this study will draw attention to how successful principals manage their schools, by providing an environment conducive to the teaching and learning process. It will demonstrate that teacher-principal relations are important, by highlighting professional development and its impact on school effectiveness and student outcomes.
\end{abstract}

Keywords: instructional leadership, personal traits, professional development, principal-teacher relations, student outcomes

\section{Introduction}

This study is grounded in the researcher's fieldwork carried out in area of education, concerning a number of educational institutes in both urban and remote areas in the Islamic Republic of Pakistan. Highlighting various aspects of these educational institutes, it is found that there are both challenges to student outcomes and potential solutions to problems in the area of school leadership; both aspects are examined here in connection with the area of students' and parents' expectations.

In terms of school leadership and management, the role of the principal as instructional leader is pivotal to overcoming the many existing problems, enhancing the school capacity, improving teachers' capabilities, and in providing a more conducive environment for teaching and learning. Effective principal leadership is also seen to improve his/ her relations with the teachers, and to strengthen the role of the local community in school improvement. In these areas, the role of principal as a mentor, and his/ her personal traits are found to assume a heightened importance.

The concept of 'Leadership' plays a pivotal role in the functioning of schools. Formal education provided by effective schools requires a specific stature, quality supporting staff, trained and qualified academic staff, and, above all, efficient and professional instructional leaders. Training good instructional leaders is the key to the whole educational process. Pakistan is a developing country facing a lot of problems in the educational system, such as a very traditional way of teaching, strong bureaucracy and insufficient budgets for education. Besides developing educational policies and visions it also a part of the country's developmental planning in education to improve its overall educational system. Bureaucracy is a significant hurdle, and many educational programmes are run without awareness of the necessary reforms to the educational system (Rizvi, 2010).

Relatively little has been written on the role and impact of educational leaders within education systems in developing countries, especially in Pakistan (Rizvi, 2010; Simkins et al., 2003). In many analysts' views, "leaders" are considered as being superior to "managers", because a leader always makes the policies while managers implement those policies. Managers try to do the right things, but the role of the leaders is different because they do things right. Thus the school principal will often play the role of the instructional leader rather than a manager or administrator, in order to do more for the betterment of the school.

While writers like (Hodgkinson, 1983) raised the interesting idea that-like financial auditors-educational auditors are responsible for imparting quality education, resulting in high achievements of students. This is what is frequently called "value-audit". As (House, 1971), in his path goal theory, identifies four types of "leader-behavior"; the first one is supportive leadership, acting for the improvement of subordinates and the provision of a good working environment for them. In the case of directive leadership, the emphasis is placed on 
the action plan, which determines how juniors will follow rules and regulations. In the participative leadership paradigm, younger colleagues are involved in decision making on all levels, while in the achievement oriented leadership visions are important and subordinates are supposed to show excellent performance in achieving targets (Ubben \& Hughes, 1997).

In addition to these initial models, a successful leader must possess some significant personal traits and considerable interpersonal skills, which play a vital role in developing the performance of the principal/leader. Perhaps, principals in the private sector can be seen to play a more positive role than in public schools in this context. Leithwood et al. (2003) and Nawab (2011) believe that one can ... "scratch the surface of an excellent school and you are likely to find an excellent principal; peer into a failing school and you will find weak leadership". Instructional leadership includes the effective development of teaching and learning activities, extensive coverage of the syllabus in time, and a keen method of supervision. All of these are possible only when the instructional leader possess adequate knowledge, skills and professional enthusiasm (Yunas \& Iqbal, 2013).

Some people are said to be a "born leaders", with definite traits, they are "true" leaders. It is often said that the behavior of the leader also depends on the type of leadership exercised: democratic, autocratic or dictatorial. It also appears to depend on the relations with group members, task value and the position held by the leader (Faisal et al., 2012). A novel paradigm of leadership, instructional leadership, is now frequently investigated and practiced in many schools. In these schools, effectiveness is thus closely related with an instructional mode of leadership. The key characteristic of instructional leaders is that they provide a good environment for working, and that efficient teamwork can be observed as being adopted in school teams. It can further be generalized that adopting a suitable type of the leadership for an organization depends upon the locality, in which that institute is located (Hallinger, 2003; Mattar, 2012).

Leadership behavior is composed of four distinguishing characteristics; these are: experience, knowledge, personal characteristics, and values and beliefs. And these characteristics have been claimed to have a significant impact on students' achievement, as well as, schools' performance (Murphy et al., 2007). Personality-wise, if a principal possess strong will power, motivational skills, soft attitude and a commanding figure, this will very likely mean that a professional principal can convert a "failing" institute into a successful institution (Chan \& Kaur, 2009). The role of the principal as an instructional leader is thus to control various functions of the school i.e. curriculum management, and staff and student supervision. However, most principals are found, on a day-to-day-basis, to be busy solving a lot of individual problems, rather than engaging in innovation and creativity. In the majority of cases studied, this is found to be the case when the system is of a "centralized" nature, i.e. no-one is found to be empowered to take action or steps towards development or improvement (Rizwan, 2011).

In addition to this, the personal values of the leader cannot be ignored for bringing about a change in the existing school scene. Some of the personal values are exhibited on a psychological level, while some pertain to acting in different groups and interacting in teams at various levels and on a number of occasions. Thus we can say that values can be obtained from the environment, friends, family members, elders or other sources (Baig \& Shafa, 2011). Effective school leaders do not concentrate on management only, but they frequently pay attention to the various challenges facing them. This means that perception of school leaders can, at times, shift to the analysis of more "active" personalities, possessing different attributes. Leaders who are thus better-equipped with active personality traits will, consequently, perform more actively in their roles (Alam, 2012).

\section{Literature Review}

The term leader is used to an individual who takes the initiative for bringing about a change in the education system, in order to achieve organizational goals. Nowadays dynamic leaders are requiring more than ever before because they can transform an existing system. Leadership is considered as key element in institutional effectiveness. It is a core element due to which private organizations are more effective than their counterpart in the public sector (Murphy et al., 2006).Issues of leadership also have play a role in education, as stated by former British prime minister Tony Blair "As new head teachers you are the critical agents for change and high standards school by school, there is literally no more important job in Britain today than yours" (Blair, 1999). Now several countries have begun to invest in leadership programmes. Researchers(Hallinger \& Heck, 1998; Muijs, 2011) suggests a relation between leadership and school efficiency. Operative leaders have an indirect influence on school capacity to improve students' outcomes, which can be due to mediocre leaders and teachers (Harris, 2004). Quality of leadership is also a factor in finding the motivational level of the teacher and improve quality of their teaching (Fullan, 2001; Muijs, 2011; Sergiovanni, 1999).Transformational leadership is a leadership that transforms individuals and organizations according to values and long term goals. 
Transformational leadership resembles with transactional leadership, which is concerned with a relationship of "exchange", for example rewards can be received from managers on the basis of extra work (Muijs, 2011). Distributed leadership, by contrast is referring to a type of leadership which involves the entire staff to lead the institute. Such leadership can stand in contradiction to transformational leadership. Distributed leadership can bring improvement (Gronn, 2000; Muijs, 2011; Muijs \& Harris, 2003). Instructional leadership is actually a command on teaching-learning process and teachers had performed theirs duty concentrating on pedagogy instead of administration and delegates with other people, focuses on students learning and give a practical shape to school vision (Hallinger \& Heck, 1998; Muijs, 2011). Leadership can be learned and it is not the inborn characteristic of a person. Recent research review shows that there is no adequate proof of a direct correlation between leadership development and improvements in organizational performance (Bush \& Glover, 2004; Muijs, 2011). However, the literature shows an indirect relationship between leadership development and effective organizational change (Berends et al., 2002; Muijs \& Harris, 2003). In the context of education sustainable leadership refers to the process of developing something which itself is nourishing. Similarly, "sustain learning" is learning which matters, which remains and engages students intellectually, socially and emotionally (Glickman, 2002; Hargreaves \& Fink, 2004). The study of the existing body of research work related to instructional leadership and its implications towards organizational commitment shows that organizational commitment of a school leader can be measured in terms of the leader's vision, student outcomes, and the creation of an enabling environment for the teaching and learning process. This is seen to draw from, and impact on, successful principal-teacher relations in schools and on the principals' own professional development.

\subsection{Principal's Vision}

Girvin (2005) has articulated that an instructional leadership role is one that promotes the goals and objectives of a given school, with a view to enhancing student achievement. In this context, the main aim of the principal is to set objectives for academic improvement, and to circulate these among the staff members as guide lines. Monitoring and supervision is also included in the principal's responsibilities, and valuation help the instructional leader to change strategy if necessary (Yunas \& Iqbal, 2013).

Leaders are often required to focus on new initiatives, with a view to achieving or altering the current goals of an organization, while administrators focuses on the implementation of the road map available to achieve the goals (Faisal et al., 2012). In this model, changes occur due to some circumstances, e.g., economic conditions, climatic changes or the unfolding of disasters. When a change takes place, the education system of any society can't remain unaffected. And schools are nurturing leaders, in order to accept the challenges of change. While (Abdullah \& Kassim, 2011; Bin Jantan, 2005) agrees that principals who are successful in effecting changing are able to make their own paradigm shift in the school system itself. In this vision for school learning, as developed by (Leithwood \& Montgomery, 1982), leaders ensure they have at their disposal a variety of data helping them to show that student performance can be used for the forging of their vision and goals (Murphy et al., 2007).

Research undertaken in different countries continues to show that leadership plays a key role in school development and any sort of change that has been brought for the development of school (Chan \& Kaur, 2009; West et al., 2000). Leadershipis almost a process which has a great impact on individuals' attitudes towards achieving their goals. The major impact of school leadership is routinely found to be on student learning (Hallinger \& Heck, 2010). In this model, the head teacher sets certain goals, like development of people i.e. making them more responsible for the performance of various tasks. School leaders thus motivate people and share their goals with subordinates, in order to make them perform more effectively.

While (Gilbert, 1998; S. H. Khan et al., 2009) found that leadership performance has two main aspects: the leadership behaviour displayed is the means, and the consequences of those behaviors are the end. When we assess the performances of head teachers, we search for instructional, behavioral, leadership, managerial and relationship qualities. Assessment of head teachers often reveals a pronounced polarity: they are either successful or not in obtaining their key goals (Khan et al., 2009). Looking towards the situation in education and its impact on the economic and social issues in any given country, it is suggested that instructional leadership can play a central role in changing the whole scenario. One key condition of this happening, however, is that leaders have a vision to run their institutes effectively by helping teachers and guiding students (Hussain, 2011).

Effective school leadership is thus a key ingredient in the facilitating of effective teaching and learning processes. School principals are the key actors charged to enhance school efficiency by bringing indispensable changes, which may result in the enhancement of the achievement, by degrees, of the grades of the students. This is possible only when the leaders plan correctly and then implement their development programs to the desired level (Yunas \& Iqbal, 2013). 


\subsection{The Relationship between Teachers \& Principals}

Relations between principals and teachers are one of the most important aspects of running an effective school. In the ideal scenario, when the school environment remains smooth, and conducive to cooperation, this is found to have a great impact on expected student outcomes. In order to enable this, principals, being leaders, should arrange regular meetings with staff, discuss various flaws observed during classroom visits and provide sufficient facilities to overcome any problems. Modifying procedures for best output provide enough information for positive change and give a feed back to teachers for the removal of deficiencies if any, probably all this will lead to school progress (Yunas \& Iqbal, 2013). Moreover, school authorities should also organize in-service training on instructional leadership, conduct seminars on behavioral change, and highlight the roles of teacher in managing change.

Thus, in short, there is a close relationship between the interactions of principals and teachers, on the one hand, and the management of expected change on the other hand (Kursunoglu \& Tanriogen, 2009). A number of analysts in the relevant literature, for example, have found strong correlations between the instructional leadership of principals' and teachers' attitudes towards impending change (Bovalino, 2007; Dixon, 1991; Hyland, 2007) as cited by (Kursunoglu \& Tanriogen, 2009). Thus, if teachers do not take interest in curricula and extra-curricular activities conducted for student development, this will make the whole picture blurred; similarly teachers' perceived lack of interest in staff meetings is also a main cause of the school failure; the blame for this will often go to the head of the institute. Thus, a good instructional leader is the one who arrange teachers' development programs, sharing views and work with staff (Niazi, 2012), and the one who exhibits a very high degree of collaboration with staff members, makes frequent visits to classrooms and gives regular feedback. Overall student guidance is also among the key responsibilities of the instructional leader (Yunas \& Iqbal, 2013). This mainly involves teachers in solving various issues, giving them the status they are perceived to deserve (Nawab, 2011).

\subsection{Community Participation}

Parents' contribution is always appreciated, it may help in solving some sort of problems; it can help in raising funds, arranging activities, providing feedback, and in many other ways. In the areas where the social economic status (SES) is low, the principals mainly concentrate on curriculum coverage and their role is task-oriented. Where SES is high, the principal do not only act conservatively; they often chose to employ motivational skills also (Mattar, 2012).

In the case of Shirin (Principal name) before training of the principals, the attitude of the local people was such that they saw themselves as responsible only for sending their kids to the school; they were not responsible for anything else. But after training, she has changed this attitude and now local people take an enhanced interest in school affairs. And she has learned the skills that how she can "link" the "inside" of the school environment, with "outside" of the community environment. She has a firm belief that without the participation of the local community no achievement is possible (Baig \& Shafa, 2011). When an instructional leader keeps ties with local community, s(he) can solve most of the upcoming problems with their consultation (Baig, 2011), since, in general, parents like to participate more actively in school activities (Alam, 2012).

\subsection{Students' Outcome}

If required resources are available and professional, skilled and well equipped staff is present in the periphery of a school, then no doubt that a school will be able to achieve the desired outcome. According to (Beck \& Murphy, 1996) human capital, financial assets and other man made things can be used to improve students' learning potential, cited by (Murphy et al., 2007). The major impact of the school leadership is that on the students learning.

Several researchers have expressed the view that school leadership has an indirect impact on student learning (Hallinger \& Heck, 2010). Simply stated, quality leadership is found to produce improvement in teaching, as well as, learning. Leadership mainly impacts on three elements in the running of schools:

Improvement of student outcomes

Improvement of the quality of staff outputs, and

Improvement of resources for better overall results (Hallinger \& Heck, 2010).

At times, it has been found that the concept of transformational leadership is also applicable to school improvement, instead of the idea of instructional leadership (Bell et al., 2003; Bossert et al., 1982; Hallinger \& Heck, 1998, 2010; Leithwood et al., 2008; Robinson et al., 2008; Witziers et al., 2003). Different researchers 
have found that transformational leadership has a measurable impact on student achievement; it can be a catalyst for the motivation of teachers to deliver higher-quality work, and for boosting the overall value of the relevant school or organization. But in this context relatively little attention has been given to students because more attention is paid to the organization (Rizwan, 2011). Principals arrange educational programs for students and always try to keep in touch with them for the solution of their problems. Students interaction not only helpful in the solution of the students problems but also provide feedback. And thus if there is any indispensable change that is required, the principal immediately takes a step (Baig, 2011).

\section{Findings}

Pakistan is a developing country, facing several problems in the education sector. Researchers tried their best to draw attention towards these problems; this study is conducted to probe the issues that are the causes of the challenging conditions in education, especially in Pakistan. The main problems highlighted, on a regular basis, by a number of researchers are:

Lack of in-service training of heads/principals

Personal traits of teachers and principals

The relations between teachers and principals

The socio-economic status of parents, and

Bureaucratic influence

Now moving towards the available evidences available in literature regarding the aforesaid factors, the foremost among them are the personal traits of the school leader (principal). A study of two principals has provided persuasive evidence for the finding that the private school principal possessed the qualities of a good administrator because he himself sometimes delivered classes; he was also engaged with the students, giving proper guidance to them and sharing the burden of his staff. He frequently visits classes. In contrast to this, many government schools principals don't take such initiatives. A number of them have been found to never utilize the resources available to them in the school and to not share knowledge. Because they knows that they can soon be transferred, many of them see no need to take such "facilitating" actions (Khan, 2013). By contrast, the major part of the instructional leadership includes an effective teaching learning activity, coverage of syllabus in time and a keen supervision. But all this is possible only when the instructional leader possess adequate knowledge, skills and professional enthusiasm (Yunas \& Iqbal, 2013).

The second part of the data analyzed is related to the characteristics possessed by a good head teacher, i.e. professional inclination, managerial skills, instructional role and leadership qualities. The most positive opinion is found to be connected to interpersonal relations and the least relevant to instructional behavior (Khan et al., 2009). Many principals' profiles show that in low achieving areas all the principals are male, while that in the high achievement areas two principals were male and two were female (Mattar, 2012). Principals in the high performing schools are actually found to be applying methods of instructional leadership more efficiently, as compared with the low-achievements schools. In both sets of schools, principals were maintaining school discipline and protecting instructional time in a better way (Mattar, 2012).

A further clear indication comes from the data that female head teachers' show better performance as instructional leaders and managers, by means of the more targeted use of inter- personal skills and "polite" attitudes (Khan et al., 2009). Many have organized sessions with community members and have raised awareness among the local members to highlight the importance of the school in advocating the skills and talents of local people (Murphy et al., 2007). This has built a good community-school relationship. It is clear that not all models of leadership play the same role. It is generally found that only learning-centered-leadership plays a more pronounced role in high performing schools (Murphy et al., 2007).

Of particular relevance in this context was one study of a female principal, who used multiple leadership styles in various situations to address a multiplicity of daily challenges and problems. She proved through her deeds that she was an effective instructional leader. In terms of her own personality-traits, she possessed strong will power, motivational skills, a "soft" attitude and a commanding figure (Chan \& Kaur, 2009). From this study, it is clear that it is not enough to apply just one type of leadership. Success depends upon the situation context, and on the choice of a leadership type and style that is most appropriate. In this context, school leaders have generally been found to have been most successful when they:

Have taken a keen interest in developing close relations with the local community

Have adopted confidence building measures 
Have shown high tolerance-levels towards criticism, and

Have afforded validity to the opinions of others (Chan \& Kaur, 2009).

This seems to indicate clearly that it is not enough to just be appointed as principal; this does not equate to the job done. On top of this, what appears important is the leadership training essential for a principal to run a school efficiently. As pointed out the importance of leadership in "changing" a system; an educational system cannot be change by merely changing one component of the system; a review of the whole system is required for bringing about, and entrenching, lasting change. The most important thing is to identify the problems; a second step is to find solutions. She suggested "seven good habits" for an academic professional to develop, as well as "five disciplines" for a good organization (Hussain, 2011).

Looking at her case, it becomes clear that training had transmitted skills to the head teacher to cope with various problems efficiently. Following the training, the head teacher eventually became a good mentor, guiding staff in finding ways of overcoming various unexpected problems and in covering their courses at the same time (Alam, 2012). Where staff were found to be unable to use equipment, the principal provided the relevant training. As a result of this, teachers now utilize their new-found skills more frequently, whilst keeping regular records (Alam, 2012).

Bush (2008) asserts that appointing administrators without adequate training is like gambling and he further states: “... it is inappropriate to gamble when the losers would be children or students (p. 33)". The lack of experience of being an educational leader is an alarming signal among principals in the Pakistani education system. There is also no particular training for principals, and "experience as a teacher" is, in itself, considered to be more than enough of a "qualification" in becoming a principal. Most post-holders have no firm communication and leadership skills, and some are not highly qualified as compared with their subordinates' qualification. They require a comprehensive training program of leadership and management (Khan, 2013). Warwick and Reimers (1995) mentioned, "With no clear definition of who they are and what they are supposed to do, schools heads are drift in the educational system [...] they were not trained to be leaders, did not see themselves as leaders, and did not act like leaders" (p. 101).

Leaders having qualifications in terms of management courses can perform better. The educational leaders whose age is less than 45 years are more active than their older colleagues. Similarly, educational leaders having experience of more than 10 years also perform in a better way (Faisal et al., 2012). Socio economic status (SES) also affects the teaching learning process (Mattar, 2012). In the areas where SES is low, the principals mainly focus on course coverage and their role is task-inclined. Where SES is high, the principals do not behave in such a conventional manner. Parents belonging to high SES areas send their children to the private schools (Mattar, 2012).

Many school leaders have no firm communication and leadership skills, and some are not highly qualified, when compared with their subordinates' qualification. Principal-teacher relations also play an important role, for instance in connection with the involvement of teachers in solving various issues, in giving them their deserved status, and in highlighting their achievements in the context of "official" functions (Nawab, 2011). It can be noted that, if the professional leaders share vision, by introducing new curricula for the future generation, as well as, new ways of teaching, this will serve to enhance their professional skills very significantly (Niazi, 2012).This means that principals who take into account any proposals submitted by the staff, place trust in their staff and implement training programs with their staff's active support, will always be considered more successful; where this is not the case, heads will face problems in achieving goals and will veer towards failure (Niazi, 2012).

In addition to this, teachers can assess their head teachers' performances as well. As (Khan et al., 2009; Mangin, 2007) argues that teachers' perceptions about "head teachers as leaders", point to an important dimension to be considered when assessing the leader's ability, which have a great significance and provide evidence for improvement of school leadership. Sometimes, the behavior of a head teacher can be unacceptable, and this is not in favor of a school environment conducive to achievement. Teachers can only perform to a satisfactory level, when the attitude of the head teacher is "democratic", instead of "autocratic" (Khan et al., 2009).

One study of head teachers in the UK and Pakistan demonstrated, head teachers at a school in Lahore were found to be more "authoritative" than "cooperative". In Pakistan and the UK, the definition of the idea of school "leadership" was also different, in term of performance and behaviour displayed (Rizwan, 2011). At Lahore, the solution to the challenges encountered was in the domain of the responsibility of head teacher only, while in Coventry it was seen as being a common task for both head teacher and staff member. In Lahore, teachers play roles as "implementers", while, by contrast to this, in Coventry, head and staff play equal roles. At Lahore, "direction" is provided by the head teacher, and the teachers just "obey", while in Coventry teachers have the 
authority to take their own initiatives for change (Rizwan, 2011).

Since the world has become a "global village", no one can find himself "isolated" in a particular place, everyone needs interaction; teachers, in particular, require constant interaction with others, in order to find a suitable position in this global village, especially if they come from peripheries. And the most suitable people for bringing about this change are the educational leaders (Hussain, 2011). As (Alam, 2012; Mangin, 2007) discusses, the principal's role as leader, manager and a change agent is very vital in this respect. Principals are responsible for working with the entire spectrum of stake holders; from students to school board members; from parents to policy makers; from teachers to local business owners; and from support staff to union officials.

\section{Discussion}

At this stage, after examining the findings of a range of different researchers, we are now in a position to add few words about the instructional role of the principal. As (Foskett \& Lumby, 2003; Goldring \& Pasternack, 1994) proposes, leadership element enhance students' performance and this quality may be seen in different people working in an educational institute. While Foskett and Lumby (2003) and Leithwood et al. (1992) consider instructional leadership as a compulsory aspect of the principal role. Since Bush and Glover (2003) and Davies (2005), in their review, define leadership as a influence which proceeds towards the achievement of goal.

The findings of the study will be discussed with help of the suggested Figure 1. The three major points are highlighted in this study; the first one is the personal traits or characteristics possessed by an instructional leader. It is not a great job to merely become a principal; of greater importance is having "leadership-qualities". Most significant amongst those appears to be the attitude of the principal, it should be democratic instead of authoritative, since a democratic, enabling, participatory, attitude contributes to creating an environment conducive to a better teaching and learning process (Abdullah \& Kassim, 2011). Relation-oriented behavior and task- oriented behavior are thus found to be mutually related. And both lead to a much higher degree of effectiveness in terms of leadership (Faisal et al., 2012).

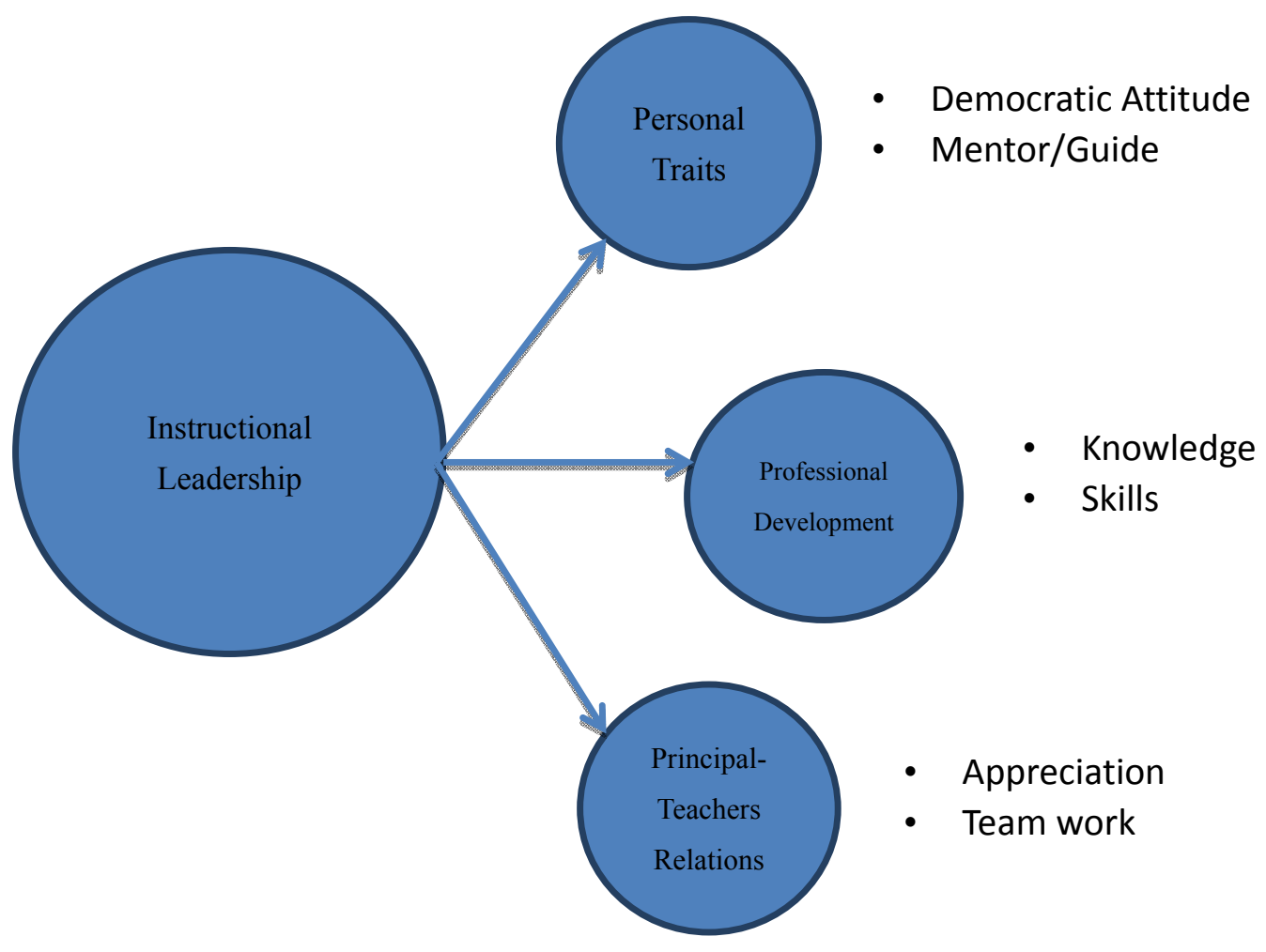

Figure 1. Instructional leadership

It has been found to be, above all else, the personal skills and personal values of school heads, which are the key 
determinants in dealing with existing problems and planning for the future (Baig, 2011). Leaders are actually role models for their followers. A teacher leaving school without prior permission, or arriving late has become a bad model. Although private school principals receive a lower wage than the government school principal they do much work (Khan, 2013). If a principal possesses sound knowledge and skills, he/she may be able to effectively work for the betterment of the organization and the welfare of the students; they will also contribute to wider society.

The major drawback in the education system of developing countries like Pakistan has been found to be that teachers are promoted as leaders without having knowledge or training in leadership. While (Alam, 2012; Kanwar, 2000) recommends that "principals need to be aware of the latest approaches in school leadership. While (Khan, 2013; Peterson, 1987) pointed out that the success of instructional programs of schools depends upon the motivational level of administrators. He added that-even if administrators have all the required skills and knowledge-their limited motivation could minimize their efficiencies.

It is worthy of note that, before offering a post to a principal, the issue of a job description is generally necessary. Teachers have a direct relation with students, teachers spend more time with students, students also consider teacher as role models. Therefore, a principal should perceive their staff as team members and always attempt to appreciate their efforts for school improvement. Where a principal acts alone as an instructional leader, school improvement, wholly depends on his/her solo efforts. Today, successful principals concentrate on the shared vision, conversation with staff, sharing knowledge and focus on students' achievements (Lambert, 2002).

In addition to this, teachers who have been inculcated into exhibiting a stronger team spirit, display higher levels of trust in their colleagues and leaders, while those who do not support the upholding of a team spirit shows less trust in their companions and in the principal (Beycioglu et al., 2012). Different forms of leadership thus have strong implications on team performance. What makes a team better than others? The simple answer to this question is leadership. A leader's vision, ability to facilitate collaboration, attitude and encouragement can provide countless opportunities to a team to perform in a better way; where this lacks, a team can be found to be lagging behind other teams (Mehra et al., 2006). Education, in this ideal model, is, therefore, a group learning activity, involving different people from the administrative function, the teaching sector, the local community, and from policy makers. The type of leadership preferred by a particular principal can set in motion a new vision of an improving and evolving organization. Distributed leadership brings an explicit change in organization, enhancing both school outcomes and students achievements (Harris \& Spillane, 2008). A good instructional leader will, for example, provide numerous opportunities to teaching staff to "co-lead", become involved and make valuable suggestions for development (Nawab, 2011).

\section{Conclusion}

After productive discussion about the various aspects of the instructional leadership, now we are in position to sum up the leverage capacities of a school principal. If the principal possess a strong potential, then s(he) might be able to run an institute successfully. On the basis of experience only designating someone as principal is like sinking a ship. Although experience has its own value, for the induction of a principal a number of criteria must be introduced.

It is thus essential, first of all, that a principal should be well equipped with knowledge and skills, which he could obtain from refresher courses, such as the whole school improvement program (WSIP). This is a program conducted in Gilgit Baltistan, Pakistan and also at Notre Dame Institute of Education (NDIE) Karachi, Pakistan which is working to produce educational leaders.

Secondly, the actual relationship between principals and teachers is important: a principal alone cannot continue his "solo flight", without a support system. The cooperation of their teachers' is essential for school effectiveness. In order to achieve this, the principals should take teachers into their confidence, share their visions, and distribute their various tasks, thus assigning importance to teachers' suggestions, and appreciating their efforts and achievements publically. S(he) will try to manage and facilitate the teachers' initiatives, expectations and performance - after all: if the teachers are not satisfied how they can perform well?

The active participation in local communities is also of fundamental importance. Through the parents' interactions with notable people of the local society, various problems can be solved. Background involvement of the parents also affects student learning.

Bureaucracy is also a hurdle in Pakistan, principals in public sector are not empowered, and they look towards being directed by hierarchical orders from "higher-up". Therefore, it can take a long time to take a decision; ultimately, late decisions cannot bring changes; neither can this solve problems. In the private sector, by contrast, 
principals have enough power to take decisions, and of course a stitch in time saves nine, when an immediate response of principals is needed to lead a school towards success and improvement.

Lot of patience, personal skills and potential, self-efficacy, coordination and commitment to boost an organization and in overall conclusion, the role of school principal is not an easy one to perform; success in this function requires achieving desire improved student outcomes.

\section{Acknowledgements}

The research is funded by Higher Education Commission (HEC) of Pakistan \& Shaheed Benazir Bhutto University, Sheringal Dir (U), Khyber Pakhtun Khwa, Pakistan.

\section{References}

Abdullah, J. B., \& Kassim, J. M. (2011). Instructional leadership and attitude towards organizational change among secondary schools principal in Pahang, Malaysia. Procedia-Social and Behavioral Sciences, 15, 3304-3309. http://dx.doi.org/10.1016/j.sbspro.2011.04.290

Alam, S. (2012). Crafting Leaders for Educational Change: Head Teacher's Perspectives. International Journal of Social Sciences and Education, 2(1), 193.

Baig, S. (2011). The personal values of school leaders in Pakistan: A contextual model of regulation and influence. The Journal of Values-Based Leadership, 4(2), 26.

Baig, S., \& Shafa, M. D. (2011). The influence of a whole school improvement program on the value orientation of a headteacher in the mountainous region of Gilgit Baltistan, Pakistan. Journal of Authentic Leadership in Education, 2(1), 1.

Beck, L. G., \& Murphy, J. (1996). The four imperatives of a successful school. ERIC.

Bell, L., Bolam, R., \& Cubillo, L. (2003). A systematic review of the impact of school headteachers and principals on student outcomes. London: EPPI-Centre.

Berends, M., Bodilly, S. J., \& Kirby, S. N. (2002). Facing the challenges of whole-school reform: New American Schools after a decade. Rand Corporation.

Beycioglu, K., Ozer, N., \& Ugurlu, C. T. (2012). Distributed leadership and organizational trust: the case of elementary schools. Procedia-Social and Behavioral Sciences, 46, 3316-3319. http://dx.doi.org/10.1016/j.sbspro.2012.06.058

Bin Jantan, A. (2005). Pengetua sekolah yang efektif. PTS Professional.

Blair, T. (1999). Labour Party conference speech. Bournemouth.

Bossert, S. T., Dwyer, D. C., Rowan, B., \& Lee, G. V. (1982). The instructional management role of the principal. Educational administration quarterly, 18(3), 34-64. http://dx.doi.org/10.1177/0013161X82018003004

Bovalino, J. W. (2007). The role of the principal in the change process: The road to inclusion. University of Pittsburgh.

Bush, T. (2008). From Management to Leadership Semantic or Meaningful Change? Educational Management Administration \& Leadership, 36(2), 271-288. http://dx.doi.org/10.1177/1741143207087777

Bush, T., \& Glover, D. (2003). School leadership: Concepts and evidence.

Bush, T., \& Glover, D. (2004). Leadership development: evidence and beliefs.

Chan, Y. F., \& Kaur, S. G. (2009). Leadership characteristics of an excellent principal in Malaysia. International Education Studies, 2(4), 106. http://dx.doi.org/10.5539/ies.v2n4p106

Davies, B. (2005). The essentials of school leadership. Paul Chapman Educational Publishing.

Dixon, V. D. (1991). A study of change: principals as facilitators and teachers as implementors during year one of an innovation. Columbia University.

Faisal, A., Azeem, M., Aysha, F., Amina, F., Saleem, F., \& Nadeem, R. (2012). Impact of Educational Leadership on Institutional Performance in Pakistan. Journal of Public Administration and Governance, 2(1), 57-94. http://dx.doi.org/10.5296/jpag.v2i1.1385

Foskett, N., \& Lumby, J. (2003). Leading and managing education: International dimensions. Sage.

Fullan, M. (2001). Leading in a culture of change. ERIC.

Gilbert, T. (1998). A Leisurely Look at Worthy Performance. In J. Woods, \& J. Gortada (Eds.), The 1998 ASTD 
Training and Performance Yearbook. New York: McGraw-Hill.

Girvin, N. (2005). The principal's role in k-12 professional development. Retrieved from http//:www.askasia.org

Glickman, C. D. (2002). Leadership for learning: How to help teachers succeed. ASCD.

Goldring, E. B., \& Pasternack, R. (1994). Principals' Coordinating Strategies and School Effectiveness 1. School Effectiveness and School Improvement, 5(3), 239-253. http://dx.doi.org/10.1080/0924345940050303

Gronn, P. (2000). Distributed properties a new architecture for leadership. Educational Management Administration \& Leadership, 28(3), 317-338. http://dx.doi.org/10.1177/0263211X000283006

Hallinger, P. (2003). Leading educational change: Reflections on the practice of instructional and transformational leadership. Cambridge Journal of education, 33(3), 329-352. http://dx.doi.org/10.1080/0305764032000122005

Hallinger, P., \& Heck, R. H. (1998). Exploring the Principal's Contribution to School Effectiveness: 1980-1995. School Effectiveness and School Improvement, 9(2), 157-191. http://dx.doi.org/10.1080/0924345980090203

Hallinger, P., \& Heck, R. H. (2010). Collaborative leadership and school improvement: Understanding the impact on school capacity and student learning. School Leadership and Management, 30(2), 95-110. http://dx.doi.org/10.1080/13632431003663214

Hargreaves, A., \& Fink, D. (2004). The seven principles of sustainable leadership. Educational Leadership, 61(7), 8-13.

Harris, A. (2004). Distributed Leadership and School Improvement Leading or Misleading? Educational Management Administration \& Leadership, 32(1), 11-24. http://dx.doi.org/10.1177/1741143204039297

Harris, A., \& Spillane, J. (2008). Distributed leadership through the looking glass. Management in Education, 22(1), 31. http://dx.doi.org/10.1177/0892020607085623

Hodgkinson, C. (1983). The philosophy of leadership.

House, R. J. (1971). A path goal theory of leader effectiveness. Administrative science quarterly, 321-339. http://dx.doi.org/10.2307/2391905

Hussain, N. (2011). Strong leadership strong institutions: It's a matter of change. PAKISTAN BUSINESS REVIEW, Pakistan.

Hyland, P. K. (2007). Resistance to Organizational Change: The Impact of Followers' Disposition Toward Change \& Supervisors' Leadership Style. Columbia University.

Kanwar, F. (2000). Secondary school head teachers' leadership styles and their implications for school improvement (Unpublished doctoral dissertation, American University in London, United Kingdom).

Khan, A. (2013). A qualitative study of foreign funded capacity development program of head teachers-Lessons from pakistan. European Journal of Business and Social Sciences, 1(12), 107-123.

Khan, S. H., Saeed, M., \& Fatima, K. (2009). Assessing the Performance of Secondary School Headteachers A Survey Study Based on Teachers' Views in Punjab. Educational Management Administration \& Leadership, 37(6), 766-783. http://dx.doi.org/10.1177/1741143209345572

Kursunoglu, A., \& Tanriogen, A. (2009). The relationship between teachers' perceptions towards instructional leadership behaviors of their principals and teachers' attitudes towards change. Procedia-Social and Behavioral Sciences, 1(1), 252-258. http://dx.doi.org/10.1016/j.sbspro.2009.01.046

Lambert, L. (2002). A framework for shared leadership. Educational leadership, 59(8), 37-40.

Leithwood, K., Harris, A., \& Hopkins, D. (2008). Seven strong claims about successful school leadership. School leadership and management, 28(1), 27-42. http://dx.doi.org/10.1080/13632430701800060

Leithwood, K., Steinbach, R., \& Begley, P. (1992). Socialization experiences: Becoming a principal in Canada. Becoming a principal: Challenges of leadership, 284-307.

Leithwood, K. A., Leithwood, K., \& Riehl, C. (2003). What we know about successful school leadership.

Leithwood, K. A., \& Montgomery, D. J. (1982). The role of the elementary school principal in program $\begin{array}{lllll}\text { improvement. Review of } & \text { Educational }\end{array}$ http://dx.doi.org/10.3102/00346543052003309

Mangin, M. M. (2007). Facilitating elementary principals' support for instructional teacher leadership. 
Educational administration quarterly, 43(3), 319-357. http://dx.doi.org/10.1177/0013161X07299438

Mattar, D. (2012). Instructional leadership in Lebanese public schools. Educational Management Administration \& Leadership, 40(4), 509-531. http://dx.doi.org/10.1177/1741143212438222

Mehra, A., Smith, B. R., Dixon, A. L., \& Robertson, B. (2006). Distributed leadership in teams: The network of leadership perceptions and team performance. The Leadership Quarterly, 17(3), 232-245. http://dx.doi.org/10.1016/j.leaqua.2006.02.003

Muijs, D. (2011). Leadership and organisational performance: From research to prescription? International Journal of Educational Management, 25(1), 45-60. http://dx.doi.org/10.1108/09513541111100116

Muijs, D., \& Harris, A. (2003). Teacher leadership-Improvement through empowerment? An overview of the literature. Educational Management Administration \& Leadership, 31(4), 437-448. http://dx.doi.org/10.1177/0263211X030314007

Murphy, J., Elliott, S. N., Goldring, E., \& Porter, A. C. (2006). Learning-Centered Leadership: A Conceptual Foundation. Learning Sciences Institute, Vanderbilt University (NJ1).

Murphy, J., Elliott, S. N., Goldring, E., \& Porter, A. C. (2007). Leadership for learning: A research-based model and taxonomy of behaviors 1. School Leadership and Management, 27(2), 179-201. http://dx.doi.org/10.1080/13632430701237420

Nawab, A. (2011). Exploring leadership practices in rural context of a developing country. International Journal of Academic Research in Business and Social Sciences, 1(3), 181. http://dx.doi.org/10.6007/ijarbss.v1i2.31

Niazi, S. (2012). School leadership and educational practices in pakistan. Dimensions, 1, 5.

Peterson, K. D. (1987). Administrative control and instructional leadership. Instructional leadership: Concepts, issues, and controversies, 139-152.

Rizvi, S. (2010). A Transnational Approach to Educational Leadership Capacity Building: A case study of the masters of education programme at Notre Dame Institute of Education, Karachi, Pakistan. Australian Catholic University.

Rizwan, R. (2011). Role of Leadership at the Head teachers' Level at Urban Primary Government Schools in Developed and Developing Countries: A Case of Schools in Coventry vs. Lahore.

Robinson, V. M., Lloyd, C. A., \& Rowe, K. J. (2008). The impact of leadership on student outcomes: An analysis of the differential effects of leadership types. Educational administration quarterly, 44(5), 635-674. http://dx.doi.org/10.1177/0013161X08321509

Sergiovanni, T. J. (1999). Refocusing Leadership to Build Community. High School Magazine, 7(1), 10-15.

Simkins, T., Sisum, C., \& Memon, M. (2003). School leadership in Pakistan: Exploring the headteacher's role. School Effectiveness and School Improvement, 14(3), 275-291. http://dx.doi.org/10.1076/sesi.14.3.275.15841

Ubben, G. C., \& Hughes, L. W. (1997). The principal: Creative leadership for effective schools. Boston: Allyn and Bacon.

Warwick, D. P., \& Reimers, F. M. (1995). Hope or despair?: Learning in Pakistan's primary schools. Greenwood Publishing Group.

West, M., Jackson, D., Harris, A., \& Hopkins, D. (2000). Learning through leadership, leadership through learning. Leadership for change and school reform, 30-49.

Witziers, B., Bosker, R. J., \& Krüger, M. L. (2003). Educational leadership and student achievement: The elusive search for an association. Educational administration quarterly, 39(3), 398-425. http://dx.doi.org/10.1177/0013161X03253411

Yunas, M., \& Iqbal, M. (2013). Dimensions of instructional leadership role of principal. Interdisciplinary Journal of Contemporary Research in Business, 4(10), 629. 


\section{Copyrights}

Copyright for this article is retained by the author(s), with first publication rights granted to the journal.

This is an open-access article distributed under the terms and conditions of the Creative Commons Attribution license (http://creativecommons.org/licenses/by/3.0/). 